\title{
UM DISCURSO \\ SOBRE AS CIÊNCIAS
}

$7^{\mathbf{a}}$ edição

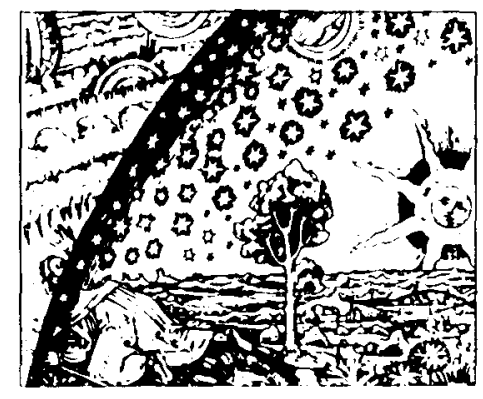

EDIÇŌES AFRONTAMENTO 
Este texto é uma versão ampliada da Oração de Sapiència prolerida na abertura solene das aulas na Universidade de Coimbra, no ano lectivo de 1985/86

I" ediçāo: Julho 1987

$2^{*}$ edição: Novembro 1988

Reimpressāo da $2^{\text {a }}$ edição: Dezembro 1989

$3^{\text {a }}$ edição: Outuhro 1990)

$4^{a}$ edição Dezembro 1990

$5^{3}$ edição Novembro 1991

$6^{\text {a }}$ edição: Maio 1993

7"edição: Janeiro 1995

Título: Um Discurso sobre as Ciências

Autor: Boaventura de Sousa Santos

(C) 1987. B. Sousa Santos e Edições Afrontamento

Edição: Ediçōes Alrontamento / R. Costa Cabral, 859 / Porto

Coleç̧ão: Histórias e Ideias / 1

N.' de ediçāo: 280

Depósito legal: 16898/87

Impressāo: I itografia Ach. Brito 
Estamos a quinze anos do final do século XX. Vivemos num tempo atónito que ao debruçar-se sobre si próprio descobre que os seus pés são um cruzamento de sombras, sombras que vêm do passado que ora pensamos já não sermos, ora pensamos não termos ainda deixado de ser, sombras que vêm do futuro que ora pensamos já sermos, ora pensamos nunca virmos a ser. Quando, ao procurarmos analisar a situação presente das ciências no seu conjunto, olhamos para o passado, a primeira imagem é talvez a de que os progressos científicos dos últimos trinta anos são de tal ordem dramáticos que os séculos que nos precederam - desde o século XVI, onde todos nós, cientistas modernos, nascemos, até ao próprio século XIX - não sāo mais que uma pré-história longínqua. Mas se fecharmos os olhos e os voltarmos a abrir, verificamos com surpresa que os grandes cientistas que estabeleceram e mapearam o campo teórico em que ainda hoje nos movemos viveram ou trabalharam entre o século XVIII e os primeiros vinte anos do século XX, de Adam Smith e Ricardo a Lavoisier e Darwin, de Marx e Durkheim a Max Weber e Pareto, de Humboldt e Planck a Poincaré e Einstein. E de tal modo é assim que é possível dizer que em termos científicos vivermos 
ainda no século XIX e que o século XX ainda nāo começou, nem talvez comece antes de terminar. $E$ se, em vez de no passado, centrarmos o nosso olhar no futuro, do mesmo modo duas imagens contraditórias nos ocorrem alternadamente. Por um lado, as potencialidades da tradução tecnológica dos conhecimentos acumulados fazem-nos crer no limiar de uma sociedade de comunicação e interactiva libertada das carências e inseguranças que ainda hoje compōem os dias de muitos de nós: o século XXI a começar antes de começar. Por outro lado, uma reflexāo cada vez mais aprofundada sobre os limites do rigor científico combinada com os perigos cada vez mais verosímeis da catástrofe ecológica ou da guerra nuclear fazem- nos temer que o século XXI termine antes de começar.

Recorrendo à teoria sinergética do físico teórico Hermann Haken, podemos dizer que vivemos num sistema visual muito instável em que a mínima flutuação da nossa percepçāo visual provoca rupturas na simetria do que vemos. Assim, olhando a mesma figura, ora vemos um vaso grego branco recortado sobre um fundo preto, ora vemos dois rostos gregos de perfil, frente a frente, recortados sobre um fundo branco. Qual das imagens é verdadeira? Ambas e nenhuma. É esta a ambiguidade e a complexidade da situação do tempo presente, um tempo de transição, síncrone com muita coisa que está além ou aquém dele, mas descompassado em relação a tudo o que o habita.

Tal como noutros períodos de transiçāo, difíceis de entender e de percorrer, é necessário voltar às coisas simples, à capacidade de formular perguntas simples, perguntas que, como Einstein costumava dizer, só uma criança pode fazer mas que, depois de feitas, são capazes de trazer uma luz nova à nossa perplexidade. Tenho comigo uma criança que há precisamente duzentos e trinta e cinco anos fez algumas perguntas simples 
sobre as ciências e os cientistas. Fê-las no início de um ciclo de produção científica que muitos de nós julgam estar agora a chegar ao fim. Essa criança é Jean-Jacques Rousseau. No seu célebre Discours sur les Siciences et les Arts (1750) Rousseau formula várias questōes enquanto responde à que, também razoavelmente infantil, lhe fora posta pela Academia de Dijon (1). Esta última questão rezava assim: o progresso das ciências e das artes contribuirá para purificar ou para corromper os nossos costumes? Trata-se de uma pergunta elementar, ao mesmo tempo profunda e fácil de entender. Para lhe dar resposta do modo eloquente que lhe mereceu o primeiro prémio e algumas inimizades - Rousseau fez as seguintes perguntas não menos elementares: há alguma relação entre a ciência e a virtude? Há alguma razāo de peso para substituirmos o conhecimento vulgar que temos da natureza e da vida e que partilhamos com os homens e mulheres da nossa sociedade pelo conhecimento científico produzido por poucos e inacessível à maioria? Contribuirá a ciência para diminuir o fosso crescente na nossa sociedade entre o que se é e n que se aparenta ser, o saber dizer e o saber fazer, entre a teoria e a prática? Perguntas simples a que Rousseau responde, de modo igualmente simples, com um redondo não.

Estávamos então em meados do século XVIII, numa altura em que a ciência moderna, saída da revolução científica do século XVI pelas mãos de Copérnico, Galileu e Newton, começava a deixar os cálculos esotéricos dos seus cultores para se transformar no fermento de uma transformação técnica e social sem precedentes na história da humanidade. Uma fase de transição, pois, que deixava perplexos os espíritos mais

(1) Jean-Jacques Rousseau, Discours sur les Sciences ef les Arts, in Oeuvres Complètes, vol. 2, Paris, Seuil, 1971, pp. 52 e ss. 
atentos e os fazia reflectir sobre os fundamentos da sociedade em que viviam e sobre o impacto das vibraçōes a que eles iam ser sujeitos por via da ordem científica emergente. Hoje, duzentos anos volvidos, somos todos protagonistas e produtos dessa nova ordem, testemunhos vivos das transformaçóes que ela produziu. Contudo, não o somos, em 1985, do mesmo modo que o éramos há quinze ou vinte anos. Por razōes que alinho adiante, estamos de novo perplexos, perdemos a confiança epistemoiógica; instalou-se em nós uma sensaçāo de perda irreparável tanto mais es tranha quanto nāo sabemos ao certo o que estamos em vias de perder; admitimos mesmo. noutros momentos, que essa sensação de perda seja apenas a cortina de medo atrás da qual se escondem as novas abundâncias da nossa vida individual e colectiva. Mas mesmo aí volta a perplexidade de nāo sabermos o que abundará em nós nessa abundância.

Daí a ambiguidade e complexidade do tempo científico presente a que comecei por aludir. Daí também a ideia, hoje partilhada por muitos, de estarmos numa fase de transição. Daí finalmente a urgência de dar resposta a perguntas simples, elementares, inteligíveis. Uma pergunta elementaré uma pergunta que atinge o magma mais profundo da nossa perplexidade individual e colectiva com a transparência técnica de uma fisga. Foram assim as perguntas de Rousseau; terão de ser assim as nossas. Mais do que isso, duzentos e tal anos depois, as nossas perguntas continuam a ser as de Rousseau. Estamos de novo regressados à necessidade de perguntar pelas relaçōes entre a ciência e a virtude, pelo valor do conhecimento dito ordinário ou vulgar que nós, sujeitos individuais ou colectivos, criamos e usamos para dar sentido às nossas práticas e que a ciência teima em considerar irrelevante, ilusório e falso; e temos finalmente de perguntar pelo papel de todo o conheci- 
mento científico acumulado no enriquecimento ou no empobrecimento prático das nossas vidas, ou seja, pelo contributo positivo ou negativo da ciência para a nossa felicidade. A nossa diferença existencial em relação a Rousseau é que, se as nossas perguntas são simples, as respostas sê-lo-ão muito menos. Estamos no fim de um ciclo de hegemonia de uma certa ordem científica. As condiçōes epistémicas das nossas perguntas estão inscritas no avesso dos conceitos que utilizamos para thes dar resposta. É necessário um esforço de desvendamento conduzido sobre um fio de navalha entre a lucidez e a ininteligibilidade da resposta. São igualmente diferentes e muito mais complexas as condições sociológicas e psicológicas do nosso perguntar. É muito diferente perguntar pela utilidade ou pela felicidade que o automóvel me pode proporcionar se a pergunta é feita quando ninguém na minha vizinhança tem automóvel, quando toda a gente tem excepto eu ou quando eu próprio tenho carro há mais de vinte anos.

Teremos forçosamente de ser mais rousseaunianos no perguntar do que no responder. Começarei por caracterizar sucintamente a ordem científica hegemónica. Analisarei depois os sinais da crise dessa hegemonia, distinguindo entre as condiçōes teóricas e as condições sociológicas da crise. Finalmente especularei sobre o perfil de uma nova ordem científica emergente, distinguindo de novo entre as condiçóes teóricas e as condiçōes sociológicas da sua emergência. Este percurso analítico será balizado pelas seguintes hipóteses de trabalho: primeiro, começa a deixar de fazer sentido a distinção entre ciências naturais e ciências sociais; segundo, a síntese que há que operar entre elas tem como pólo catalisador as ciências sociais; terceiro, para isso, as ciências sociais terão de recusar todas as formas de positivismo lógico ou empírico ou de mecinnicismo materialista ou idealista com a consequente revalorização do 
que se convencionou chamar humanidades ou estudos humanísticos; quarto, esta síntese não visa uma ciência unificada nem sequer uma teoria geral, mas tāo-só um conjunto de galerias temáticas onde convergem linhas de água que até agora concebemos como objectos teóricos estanques; quinto, à medida que se der esta síntese, a distinçāo hierárquica entre conhecimento científico e conhecimento vulgar tenderá a desaparecer e a prática será o fazer e o dizer da filosofia da prática.

\section{() PARADIGMA DOMINANTE}

$\mathrm{O}$ modelo de racionalidade que preside à ciência moderna constituiu-se a partir da revolução científica do século XVI e foi desenvolvido nos séculos seguintes basicamente no domínio das ciências naturais. Ainda que com alguns prenúncios no século XVIII. é só no século XIX que este modelo de racionalidade se estende às ciências sociais emergentes. A partir de então pode falar-se de um modelo global de racionalidade científica que admite variedade interna mas que se distingue e defende, por via de fronteiras ostensivas e ostensivamente policiadas, de duas formas de conliecimento não científico (e, portanto, irracional) potencialmente perturbadoras e intrusas: 0 senso comum e as chamadas humanidades ou estudos humanísticos (em que se incluiram, entre outros, os estudos históricos, filológicos, jurídicos, litcrários, filosóficos e teológicos)!

Sendo um modelo global, a nova racionalidade cientifica é 
também um modelo totalitário, na medida em que nega o carácter racional a todas as formas de conhecimento que se não pautarem pelos seus princípios epistemológicos e pelas suas regras metodológicas. É esta a sua característica fundamental e a que melhor simboliza a ruptura do novo paradigma científico com os que o precedem. Está consubstanciada, com crescente definiçāo, na teoria heliocêntrica do movimento dos planetas de Copérnico, nas leis de Kepler sobre as órbitas dos planetas, nas leis de Galileu sobre a queda dos corpos, na grande síntese da ordem cósmica de Newton e finalmente na consciência filosófica que the conferem Bacon e sobretudo Descartes. Esta preocupação em testemunhar uma ruptura fundante que possibilita uma e só uma forma de conhecimento verdadeiro está bem patente na atitude mental dos protagonistas, no seu espanto perante as próprias descobertas e a extrema e ao mesmo tempo serena arrogância com que se medem com os seus contemporâneos. Para citar apenas dois exemplos, Kepler escreve no seu livro sobre a Harmonia do Mundo publicado em 1619, a propósito das harmonias naturais que descobrira nos movimentos celestiais: "Perdoai-me mas estou feliz; se vos zangardes eu perseverarei; (...) O meu livro pode esperar muitos sé. culos pelo seu leitor. Mas mesmo Deus teve de esperar seis mil anos por aqueles que pudessem contemplar o seu trabalho» (2). Por outro lado, Descartes, nessa maravilhosa autobiografia espiritual que é o Discurso do Método e a que voltarei mais tarde, diz, referindo-se ao método por si encontrado: «Porque já colhi dele tais frutes que embora no juízo que faço de mim próprio procure sempre inclinar-me mais para o lado

(2) Consultada a ediçāo alemí (introduçấo e tradução de Max Caspar), Johammes Kepler, Well-llarmonik. Munique, Verlag Oldenbourg. 1939, p. 280. 
da desconfiança do que para o da presunçāo, e embora, olhando com olhar de filósofo as diversas acçōes e empreendimentos de todos os homens, nāo haja quase nenhuma que não me pareça vã e inútil, não deixo de receber uma extrema satisfação com o progresso que julgo ter feito em busca da verdade e de conceber tais esperanças para o futuro que, se entre as ocupações dos homens, puramente homens, alguma há que seja solidamente boa e importante, ouso crer que é aquela que escolhi» (3).

Para compreender esta confiança epistemológica é necessário descrever, ainda que sucintamente, os principais traços do novo paradigma científico. Cientes de que o que os separa do saber aristotélico e medieval ainda dominante não é apenas nem tanto uma melhor observação dos factos como sobretudo uma nova visāo do mundo e da vida, os protagonistas do novo paradigma conduzem uma luta apaixonada contra todas as formas de dogmatismo e de autoridade. O caso de Galileu é particularmente exemplar, e é ainda Descartes que afirma: «Eu não podia escolher ninguém cujas opiniōes me parecessem dever ser preferidas às dos outros, e encontrava-me como que obrigado a procurar conduzir-me a mim próprion (4). Esta nova visão do mundo e da vida reconduz-se a duas distinçōes fundamentais, entre conhecimento científico e conhecimento do senso comum, por um lado, e entre natureza e pessoa humana, por outro. Ao contrário da ciência aristotélica, a ciência moderna desconfia sistematicamente das evidências da nossa experiência imediata. Tais evidências, que estāo na base do conhecimento vulgar, são ilusórias. Como bem salienta Einstein

(3) Descartes, Discurson do Método e as Pairōes da Almu. Lisboa, Sá da Costa. 1984, p. 6.

(4) Descartes, ob. cit., p. 16. 
no prefáciu ao Diálogo sobre os Grandes Sistemas do Mundo, Galileu esforça-se denodadamente por demonstrar que a hipótese dos movimentos de rotaçāo e de translaçāo da terra não é refutada pelo facto de não observarmos quaisquer efeitos mecânicos desses moviment ss, ou seja, pelo facto de a terra nos parecer parada e quieta (5). Por outro lado, é total a separação entre a natureza e o ser humano. A natureza é tão-só extensão e movimento; é passiva, eterna e reversível, mecanismo cujos elementos se podem desmontar e depois relacionar sob a forma de leis; não tem qualquer outra qualidade ou dignidade que nos impeça de desvendar os seus mistérios, desvendamento que nāo é contemplativo, mas antes activo, já que visa conhecer a natureza para a dominar e controlar. Como diz Bacon, a ciência fará da pessoa humana «o senhor e o possuidor da natureza» $(6)$.

Com base nestes pressupostos o conhecimento científico avança pela observação descomprometida e livre, sistemática e tanto quanto possível rigorosa dos fenómenos naturais. $\mathrm{O}$ Novum Organum opōe a incerteza da razāo entregue a si mesma à certeza da experiência ordenada (7). Ao contrário do que pensa Bacon, a experiência nāo dispensa a teoria prévia, $o$ pensamento dedutivo ou mesmo a especulação, mas força

(5) Einstein in Galileu, Dialogue Concerning the Two Chief World Systems. Berkeley, University of Califomia Press, 1970, p. XVII.

(6) Consultada a edição espanhola (preparada e traduzida por Gallach Palés), F. Bacon, Novum Organum. Madrid, Nueva Biblioteca Filosófica, 1933. Para Bacon «a senda que conduz o homem ao poder e a que o conduz à ciência estão muito próximas, sendo quase a mesma" (p. 110). Se o objectivo da ciência é dominar a natureza não é menos verdade que "só podemos vencer a natureza obedecendo-lhen (p. 6, sublinhado meu), o que nem sempre tem sido devidamente salientado nas interpretaçóes da teoria de Bacon sobre a ciência.

(7) Cfr. A. Koyré. Consideraçoess solbre Descartes. Lisboa, Presença, 1981, p. 30. 
qualquer deles a nāo dispensarem, enquanto instância de confirmaçāo última, a observaçāo dos factos. Galileu só refuta as deduçōes de Aristóteles na medida em que as acha insustentáveis e é ainda Einstein quem nos chama a atençāo para o facto de os métodos experimentais de Galileu serem tão imperfeitos que só por via de especulaçōes ousadas poderia preencher as lacunas entre os dados empíricos (basta recordar que não havia mediçōes de tempo inferiores ao segundo) ${ }^{(8)}$. Descartes, por seu tumo, vai inequivocamente das ideias para as coisas e não das coisas para as ideias e estabelece a prioridade da metafísica enquanto fundamento último da ciência.

As ideias que presidem à observação e à experimentaçāo são as ideias claras e simples a partir das quais se pode ascender a um conhecimento mais profundo e rigoroso da natureza. Essas ideias são as ideias matemáticas. A matemática fornece à ciência moderna, não só o instrumento privilegiado de análise, como também a lógica da investigaçāo, como ainda o modelo de representaçĩo da própria estrutura da matéria. Para Galileu, o livro da natureza está inscrito em caracteres geométricos (9) e Einstein não pensa de modo diferente (10). Deste

(8) Einstein, ob. cit., p. XIX.

(9) Entre muitos outros passos do Diálogo sobre os Grandes Sistemas, cfr. a seguinte fala de Salviati: "No que respeita à compreensāo intensivi e na medida em que este termo denota a compreensäo perfeita de alguma proposição, digo que a inteligência humana compreende algumas delas perfeitamente, e que, portanto, a respeito delas tem uma centeza tāo absoluta quanto a própria natureza. Tais são as proposiçōes das ciências matemáticas, isto é, da geometria e da aritmética nas quais a inteligência divina conhece infinitamente mais proposiçóes porque as conhece todas. $M$ as no que respeita àquelas poucas que a inteligência humana compreende, penso que o seu conhecimento é igual ao Divino em certeza objectiva porque, nesses casos, consegue compreender a necessidade para além da qual não há maior centeza”. Galileu, ob. cit., p. 103.

(10) A admiração de Einstein por Galileu está beın expressa no prefá(io referido na nota 5.0 modo radical (e instintivo) como Finstein "vê" 
lugar central da matemática na ciência moderna derivam duas consequências principais. Em primeiro lugar, conhecer significa quantificar. $O$ rigor científico afere-se pelo rigor das mediçōes. As qualidades intrínsecas do objecto são, por assim dizer, desqualificadas e em seu lugar passam a imperar as quantidades em que eventualmente se podem traduzir. O que não é quantificável é cientificamente irrelevante. Em segundo lugar, o método científico assenta na redução da complexidade. $O$ mundo é complicado e a mente humana não o pode compreender completamente. Conhecer significa dividir e classificar para depois poder determinar relações sistemáticas entre o que se separou. Já em Descartes uma das regras do Mérodo consiste precisamente em «dividir cada uma das dificuldades... em tantas parcelas quanto for possivel e requerido para melhor as resolver» (11). A divisāo primordial é a que distingue entre "condiçōes iniciais» e "leis da natureza». As condiçōes iniciais são o reino da complicaçāo, do acidente e onde é necessário seleccionar as que estabelecem as condiçóes relevantes dos factos a observar; as leis da natureza sāo o reino da simplicidade e da regularidade onde é possível observar e medir com rigor. Esta distinção entre condiçōes iniciais e leis da natureza nada tem de «natural». Como bem observa Eugene Wigner, é mesmo completamente arbitrária ${ }^{(12)}$. No entanto, é nela que assenta toda a ciência moderna.

A natureza teórica do conhecimento científico decorre dos pressupostos epistemológicos e das regras metodológicas já

a natureza matemática da estrutura da matéria explica em parte a sua longa batalha sobre a interpretação da mecânica quântica (especialmente contra a interpretaçāo de Copenhague). Cfr. B. Hoffmann, Albert Einstein, Creator and Rebel, Nova Lorque, New American Library. 1973, pp. 173 e ss.

(11) Descartes, ob. cil., p. 17.

(12) E. Wigner, Symmetries and Reflections. Scientific Essays. Cambridge, Cambridge University Press, 1970. p. 3. 
referidas. É um conhecimento causal que aspira à formulação de leis, à luz de regularidades observadas, com vista a prever o comportamento futuro dos fenómenos. A descoberta das leis da natureza assenta, por um lado, e como já se referiu, no isolamento das condições iniciais relevantes (por exemplo, no caso da queda dos corpos, a posiçáo inicial e a velocidade do corpo em queda) e, por outro lado, no pressuposto de que o resultado se produzirá independentemente do lugar e do tempo em que se realizarem as condiçōes iniciais. Por outras palavras, a descoberta das leis da natureza assenta no princípio de que a posição absoluta e o tempo absoluto nunca são condiçōes iniciais relevantes. Este princípio é, segundo Wigner, o mais importante teorema da invariância na física clássica (13).

As leis, enquanto categorias de inteligibilidade, repousam num conceito de causalidade escolhido, não arbitrariamente, entre os oferecidos pela física aristotélica. Aristóteles distingue quatro tipos de causa: a causa material, a causa formal, a causa eficiente e a causa final. As leis da ciência moderna são um tipo de causa formal que privilegia o como funciona das coisas em detrimento de qual o agente ou qual o fim das coisas. É por esta via que o conhecimento científico rompe com o conhecimento do senso comum. É que, enquanto no senso comum, e portanto no conhecimento prático em que ele se traduz, a causa e a intenção convivem sem problemas, na ciência a determinação da causa formal obtém-se com a expulsão da intenção. É este tipo de causa formal que permite prever e, portanto, intervir no real e que, em última instância, permite à ciência moderna responder à pergunta sobre os fundamentos do seu rigor e da sua verdade com o elenco dos seus êxitos na

(13) E. Wigner, oh. cit., p. 226. 
manipulaçāo e na transformação do real.

Um conhecimento baseado na formulação de leis tem como pressuposto metateórico a ideia de ordem e de estabilidade do mundo, a ideia de que o passado se repete no futuro. Segundo a mecânica newtoniana, o mundo da matéria é uma máquina cujas operaçōes se podem determinar exactamente por meio de leis físicas e matemáticas, um mundo estático e eterno a flutuar num espaço vazio, um mundo que o racionalismo cartesiano torna cognoscível por via da sua decomposição nos elementos que o constituem. Esta ideia do mundo-máquina é de tal modo poderosa que se vai transformar na grande hipótese universal da época moderna, o mecanicismo. Pode parecer surpreendente e até paradoxal que uma forma de conhecimento, assente numa tal visão do mundo, tenha vindo a constituir um dos pilares da ideia de progresso que ganha corpo no pensamento europeu a partir do século XVIII e que é o grande sinal intelectual da ascensão da burguesia (14). Mas a verdade é que a ordem e a estabilidade do mundo sāo a pré-condição da transformação tecnológica do real.

$O$ determinismo mecanicista é o horizonte certo de uma forma de conhecimento que se pretende utilitário e funcional, reconhecido menos pela capacidade de compreender profundamente o real do que pela capacidade de o dominar e transformar. No plano social, é esse também o horizonte cognitivo mais adequado aos interesses da burguesia ascendente que via na sociedade em que começava a dominar o estádio final da evolução da humanidade (o estado positivo de Comte; a sociedade industrial de Spencer; a solidariedade orgânica de Durkheim). Daí que o prestígio de Newton e das leis simples a

(14) Cfr., entre muitos, S. Pollard, The ldea of Progress. Londres, Penquin. 1971, p. 39. 
que reduzia toda a complexidade da ordem cósmica tenham convertido a ciência moderna no modelo de racionalidade hegemónica que a pouco e pouco transbordou do estudo da natureza para o estudo da sociedade. Tal como foi possivel descobrir as leis da natureza, seria igualmente possível descobrir as leis da sociedade. Bacon, Vico e Montesquieu são os grandes precursores. Bacon afirma a plasticidade da natureza humana e, portanto, a sua perfectibilidade, dadas as condiçóes sociais, jurídicas e políticas adequadas, condiçōes que é possível determinar com rigor (15). Vico sugere a existência de leis que governam deterministicamente a evoluçāo das sociedades e tornam possivel prever os resultados das acçōes colectivas. Com extraorciinária premonição Vico identifica e resolve a contradição entre a liberdade e a imprevisibilidade da acçāo humana individual e a determinaçāo e previsibilidade da acçāo colectiva (16). Montesquieu pode ser considerado um precursor da sociologia do direito ao estabelecer a relaçāo entre as leis do sistema jurídico, feitas pelo homem, e as leis inescapáveis da natureza (17).

No século XVIII este espírito precursor é ampliado e aprofundado e o fermento intelectual que daí resulta, as luzes, vai criar as condiçōes para a emergência das ciências sociais no século XIX. A consciência filosófica da ciência moderna, que tivera no racionalismo cartesiano e no empirismo baconiano as suas primeiras formulações, veio a condensar-se no positivismo oitocentista. Dado que, segundo este, só há duas formas de conhecimento científico - as disciplinas formais da lógica e da matemática e as ciências empíricas segundo o modelo mecanicista das ciências naturais - as ciências sociais nasce-

(15) Bacon, ob. cit.

(16) Vico, Scienza Nuora, in Opere. Milão, Riccardi. 1953.

(17) Montesquieu. L'Tsprit des Lois. Par is. Les Belles-1 ettres. 1950. 
ram para ser empíricas. $\mathrm{O}$ modo como o modelo mecanicista foi assumido foi, no entanto, diverso. Distingo duas vertentes principais: a primeira, sem dúvida dominante, consistiu em aplicar, na medida do possível, ao estudo da sociedade todos os princípios epistemológ cos e metodológicos que presidiam ao estudo da natureza desile o século XVI; a segunda, durante muito tempo marginal mas hoje cada vez mais seguida, consistiu em reivindicar para as ciências sociais um estatuto epistemológico e metodológico próprio, com base na especificidade do ser humano e sua distinção polar em relação à natureza. Estas duas concepçōes têm sido consideradas antagónicas, a primeira, sujeita ao jugo positivista, a segunda, liberta dele, e qualquer delas reivindicando o monopólio do conhecimento científico-social. Apresentarei adiante uma interpretaçāo diferente, mas para já caracterizarei sucintamente cada uma destas variantes.

A primeira variante - cujo compromisso epistemológico está bem simbolizado no nome de "física social» com que inicialmente se designaram os estudos científicos da sociedade - parte do pressuposto que as ciências naturais são uma aplicação ou concretização de um modelo de conhecimento universalmente válido e, de resto, o único válido. Portanto, por maiores que sejam as diferenças entre os fenómenos naturais e os fenómenos sociais é sempre possível estudar os últimos como se fossem os primeiros. Reconhece-se que essas diferenças actuam contra os fenómenos rociais, ou seja, tornam mais difícil o cumprimento do cânone metodológico e menos rigoroso o conhecimento a que se chega, mas não há diferenças qualitativas entre o processo científico neste domínio e o que preside ao estudo dos fenómenos naturais. Para estudar os fenómenos sociais como se fossem fenómenos naturais, ou seja, para conceber os factos sociais como coisas, como pre- 
tendia Durkheim (18), o fundador da sociologia académica, é necessário reduzir os factos sociais às suas dimensóes externas, observáveis e mensuráveis. As causas do aumento da taxa de suicídio na Europa do virar do século não são procuradas nos motivos invocados pelos suicidas e deixados em cartas, como é costume, mas antes a partir da verificação de regularidades em função de condições tais como o sexo, o estado civil, a existência ou não de filhos, a religião dos suicidas (19).

Porque essa redução nem sempre é fácil e nem sempre se consegue sem distorcer grosseiramente os factos ou sem os reduzir à quase irrelevância, as ciências sociais têm um longo caminho a percorrer no sentido de se compatibilizarem com os critérios de cientificidade das ciências naturais. Os obstáculos sāo enormes mas não sāo insuperáveis. Ernest Nagel, em The Structure of Science, simboliza bem o esforço desenvolvido nesta varianie para identificar os obstáculos e apontar as vias da sua superação. Eis alguns dos principais obstáculos: as ciências sociais naio dispōem de teorias explicativas que thes permitam abstrair do real para depois buscar nele, de modo metodologicamente controlado, a prova adequada; as ciências sociais não podem estabelecer leis universais porque os $\mathrm{fe}$ nómenos sociais são historicamente condicionados e culturalmente determinados; as ciências sociais não podem produzir previsōes fiáveis porque os seres humanos modificam o seu comportamento $\mathrm{em}$ funçăo do conhecimento que sobre ele se adquire; os fenómenos sociais sāo de natureza subjectiva e como tal náo se deixam captar pela objectividade do comportamento; as ciências sociais nāo são objectivas porque o cien-

(18) E. Durkheim, Ais Regras do Método Socinlógirn. Lisboa, Presen(̧a, 1980 .

(19) E. Durkheim, O Suicídie. Lisboa, Presença, 1973. 
tista social não pode libertar-se, no acto de observação, dos valores que informam a sua prática em geral e, portanto, também a sua prática de cientista (20).

Em relaçāo a cada um destes obstáculos, Nagel tenta demonstrar que a oposição cntre as ciências sociais e as ciências naturais não é tão linear quanto se julga e que, na medida em que há diferenças, elas são superáveis ou negligenciáveis. Reconhece, no entanto, que a superação dos obstáculos nem sempre é fácil e que essa é a razāo principal do atraso das ciências sociais em relação às ciências naturais. $A$ ideia do atraso das ciências sociais é a ideia central da argumentaçāo metodológica nesta variante, e, com ela, a ideia de que esse atraso, com tempo e dinheiro, poderá vir a ser reduzido ou mesmo eliminado.

$\mathrm{Na}$ teoria das revoluçóes científicas de Thomas Kuhn o atraso das ciências sociais é dado pelo carácter pré-paradigmático destas ciências, ao contrário das ciências naturais, essas sim, paradigmáticas. Enquanto, nas ciências naturais, o desenvolvimento do conhecimento tornou possível a formulação de um conjunto de princípios e de teorias sobre a estrutura da matéria que são aceites sem discussão por toda a comunidade científica, conjunto esse que designa por paradigma, nas ciências sociais nāo há consenso paradigmático, pelo que o debate tende a atravessar verticalmente toda a espessura do conhecimento adquirido. O esforço e o desperdício que isso acarreta é simultaneamente causa e efeito do atraso das ciências sociais.

A segunda vertente reivindica para as ciências sociais um estatuto metodológico próprio. Os obstáculos que há pouco enunciei são, segundo esta vertente, intransponíveis. Para alguns, é a própria ideia de ciência da sociedade que está em

(20) Emest Nagel, The Structure of Science. Problems in the Logic. of Scientific Explanation. Nova Iorque, Harcourt, Brace \& World, 1961. pp. 447 e ss. 
causa, para outros trata-se tāo-só de empreender uma ciência diferente. $\mathrm{O}$ argumento fundamental é que a acçāo humana é radicalmente subjectiva. O comportamento humano, ao contrário dos ienómenos naturais, nāo pode ser descrito e muito menos explicado com base nas suas características exteriores e objectiváveis, uma vez que o mesmo acto externo pode corresponder a sentidos de aç̧ão muito diferentes. A ciência social será sempre uma ciência subjectiva e nāo objectiva como as ciências naturais; tem de compreender os fenómenos sociais a partir das atitudes mentais e do sentido que os agentes conferem às suas acçōes, para o que é necessário utilizar métodos de investigação e mesmo critérios epistemológicos diferentes dos correntes nas ciências naturais, métodos qualitativos em vez de quantitativos, com vista à obtenção de um conhecimento intersubjectivo, descritivo e compreensivo, em vez de um conhecimento objectivo, explicativo e nomotético.

Esta concepção de ciência social reconhece-se numa postura antipositivista e assenta na tradição filosólica da fenomenologia e nela convergem diferentes variantes, desde as mais moderadas (como a de Max Weber) (21) até às mais extremistas (como a de Peter Winch) (22). Contudo, numa reflexão mais aprofundada, esta concepção, tal como tem vindo a ser elaborada, revela-se mais subsidiária do modelo de racionalidade das ciências naturais do que parece. Partilha com este modelo a distinção natureza/ser humano e tal como ele tem da natureza uma visão mecanicista à qual contrapōe, com evidência esperada, a especificidade do ser humano. A esta distinção, primordial na revolução científica do século XVI, vão-

(21) Max Weber, Methodologischen Schriften. Frankfurt. Fischer, 1968.

(22) Peter Winch, The Idea of a Social Science and its Relation to Philosophy. I ondres. Routledge e Kegan Paul. 1970. 
- se sobrepor nos séculos seguintes outras, tal como a distinçāo natureza/cultura e a distinçāo ser humano/animal, para no século XVIII se poder celebrar o carácter único do ser humano. A fronteira que então se estabelece entre o estudo do ser humano e o estudo da ratureza não deixa de ser prisioneira do reconhecimento da prioridade cognitiva das ciências naturais, pois, se, por um lado, se recusarr. os condicionantes biológicos do comportamento humano, pelo outro usam-se argumentos biológicos para fixar a especificidade do ser humano. Pode, pois, concluir-se que ambas as concepçōes de ciência social a que aludi pertencem ao paradigma da ciência moderna, ainda que a concepçāo mencionada em segundo lugar represente, dentro deste paradigma, um sinal de crise e contenha alguns dos componentes da transição para um outro paradigma científico.

\section{A CRISE DO PARADIGMA DOMINANTE}

São hoje muitos e fortes os sinais de que o modelo de racionalidade científica que acabo de descrever em alguns dos seus traços principais atravessa uma profunda crise. Defenderei nesta seç̧ão: primeiro, que essa crise é não só profunda como irreversível; segundo, que estamos a viver um período de revolução científica que se iniciou com Einstein e a mecânica quântica e nāo se sabe ainda quando acabará; terceiro, que os sinais nos permitem tāo-só especular acerca do paradigma que cmergirá deste período revolucionário mas que, desde já, 
se pode afirmar com segurança que colapsarāo as distinçōes básicas em que assenta o paradigma dominante e a que aludi na seç̧ão precedente.

A crise do paradigma dominante é o resultado interactivo de uma pluralidade de condiçōes. Distingo entre condiçōes sociais e condiçōes teóricas. Darei mais atenção às condiçōes teóricas e por elas começo. A primeira observaçāo, que não é tão trivial quanto parece, é que a identificação dos limites, das insuficiências estruturais do paradigma científico moderno é o resultado do grande avanço no conhecimento que ele propiciou. O aprofundamento do conhecimento permitiu ver a fragilidade dos pilares em que se funda.

Einstein constitui o primeiro rombo no paradigma da ciência moderna, um rombo, aliás, mais importante do que o que Einstein foi subjectivamente capaz de admitir. Um dos pensamentos mais profundos de Einstein é o da relatividade da simultaneidade. Einstein distingue entre a simultaneidade de acontecimentos presentes no mesmo lugar e a simultaneidade de acontecimentos distantes, em particular de acontecimentos separados por distâncias astronómicas. Em relaçāo a estes últimos, o problema lógico a resolver é o seguinte: como é que o observador estabelece a ordem temporal de acontecimentos no espaço? Certamente por mediçōes da velocidade da luz, partindo do pressuposto, que é fundamental à teoria de Einstein, que não há na natureza velocidade superior à da luz. No entanto, ao medir a velocidade numa direção única (de $\mathrm{A}$ a B), Einstein defronta-se com um círculo vicioso: a fim de determinar a simultaneidade dos acontecimentos distantes é necessário conhecer a velocidade; mas para medir a velocidade é necessário conhecer a simultaneidade dos acontecimentos. Com um golpe de génio, Einstein rompe com este círculo, demonstrando que a simultaneidade de acontecimentos distantes 
não pode ser verificada, pode tão-só ser definida. É, portanto, arbitrária e daí que, como salienta Reichenbach, quando fazemos mediçóes não pode haver contradiçōes nos resultados uma vez que estes nos devolverāo a simultaneidade que nós introduzimos por definiçāo no sistema de medição (23). Esta teoria veio revolucionar as nossas concepçōes de espaço e de tempo. Não havendo simultaneidade universal, o tempo e o espaço absolutos de Newton deixam de existir. Dois acontecimentos simultâneos num sistema de referência não são simultâneos noutro sistema de referência. As leis da física e da geometria assentam em mediçōes locais. "Os instrumentos de medida, sejam relógios ou metros, não têm magnitudes independentes, ajustam-se ao campo métrico do espaço, a estrutura do qual se manifesta mais claramente nos raios de luz» (24).

O carácter local das mediçóes e, portanto, do rigor do conhecimento que com base nelas se obtém, vai inspirar o surgimento da segunda condição teórica da crise do paradigma dominante, a mecânica quântica. Se Einstein relativizou o rigor das leis de Newton no domínio da astrofísica, a mecânica quântica fêtlo no domínio da microfísica. Heisenberg e Bohr demonstram que não é possível observar ou medir um objecto sem interferir nele, sem o alterar, e a tal ponto que o objecto que sai de um processo de medição não é o mesmo que lá entrou. Como ilustra Wigner, «a medição da curvatura do espaço causada por uma partícula nāo pode ser levada a cabo sem criar novos campos que são biliões de vezes maiores que o campo sob investigação» (25). $\Lambda$ ideia de que não conhecemos do real

(23) H. Reichenbach, From Copernicus te Einstein. Nova Iorque, Dover Publications, 1970, p. 60.

(24) H. Reichenbach, ob. cil., p. 68.

(25) E. Wigner, ob. cit. p. 7. 
senāo o que nele introduzimos, ou seja, que não conhecemos do real senāo a nossa intervenção nele, está bem expressa no princípio da incerteza de Heisenberg: não se podem reduzir simultaneamente os erros da medição da velocidade e da posição das partículas; o que for feito para reduzir o erro de uma das medições aumenta o erro da outra (26). Este princípio, e, portanto, a demonstração da interferência estrutural do sujeito no objecto observado, tem implicaçōes de vulto. Por um lado, sendo estruturalmente limitado o rigor do nosso conhecimento, só podemos aspirar a resultados aproximados e por isso as leis da física são tão-só probabilísticas. Por outro lado, a hipótese do determinismo mecanicista é inviabilizada uma vez que a totalidade do real não se reduz à soma das partes em que a dividimos para observar e medir. Por último. a distinção sujeito/objecto é muito mais complexa do que à primeit" . "ita pode parecer. A distinção perde os seus contornos dicotómicos e assume a forma de um continuum.

O rigor da medição posto em causa pela mecânica quântica será ainda mais profundamente abalado se se questionar o rigor do veículo formal em que a medição é expressa, ou seja, o rigor da matemática. $\hat{E}$ isso o que sucede com as investigações de Gödel e que por essa razão considero serem a terceira condição da crise do paradigma. O teorema da incompletude (ou do não completamento) e os teoremas sobre a impossibilidade, em certas circunstâncias, de encontrar dentro de um dado sistema formal a prova da sua consistência vieram mostrar que, mesmo seguindo à risca as regras da lógica matemática, é possível formular proposiçōes indecidiveis, proposi-

(26) W. Heisenberg, A Imagem da Natureza na Física Moderna. Lisboa, Livros do Brasil, sid.: W. Ileisenberg. Phisics and Bevond. Londres, Allen and Unwin. 1971. 
çōes que se não podem demonstrar nem refutar, sendo que uma dessas proposições é precisamente a que postula o carácter nāo-contraditório do sistema (27). Se as leis da natureza fundamentam o seu rigor no riģor das formalizações matemáticas em que se expressam, as inv :stigaçōes de Gödel vêm demonstrar que o rigor da matemática carece ele próprio de fundamento. A partir daqui é possível não só questionar o rigor da matemática como também redefini-lo enquanto forma de rigor que se opóe a outras formas de rigor alternativo, uma forma de rigor cujas condiçōes de êxito na ciência moderna não podem continuar a ser concebidas como naturais e óbvias. A própria filosofia da matemática, sobretudo a que incide sobre a experiência matemática, tem vindo a problematizar criativamente estes temas e reconhece hoje que o rigor matemático, como qualquer outra forma de rigor, assenta num critério de selectividade e que, como tal, tem um lado construtivo e um lado destrutivo.

A quarta condição teórica da crise do paradigma newtoniano é constituída pelos avanços do conhecimento nos domínios da microfísica, da química e da bioiogia nos últimos vinte anos. A título de exemplo, menciono as investigaçōes do físico- químico llya Prigogine. A teoria das estruturas dissipativas e o princípio da «ordem através de flutuaçōes» estabelecem que em sistemas abertos, ou seja, em sistemas que funcionam nas margens da estabilidade, a evoluçāo explica-se por flutuaçōes

(27) O impacto dos teoremas de Gödel na filosofia da ciência tem sido diversamente avaliado. Cfr., por exemplo, J. Ladrière, "Les Limites de la Formalization", in J. Piaget (org.). Legique et Connaissance Scientifique. Paris, Gallimard, 1967, pp. 312 e ss; R. Jones, Physics as Metaphor. Nova lorque, New American Library, 1982, p. 158; J. Parain-Vial, Philosophie des Sciences de la Nature. Tendances Nouvelles. Paris, Klincksieck, 1983, pp. 52 e ss.; R. Thom, Paráholas e Catístrofes. Lisboa, D. Quirote, 1985, p. 36: J. Briggs e F. D. Peat, Looking Glass Universe. The Emerging Science of Wholeness. Londres, Font:ana. 1985, p. 22. 
de energia que em determinados momentos, nunca inteiramente previsíveis, desencadeiam espontaneamente reacçōes que, por via de mecanismos não lineares, pressionam o sistema para além de um limite máximo de instabilidade e o conduzem a um novo estado macroscópico. Esta transformaçāo irreversível e termodinâmica é o resultado da interacção de processos microscópicos segundo uma lógica de auto-organização numa situação de não-equilíbrio. A situação de bifurcação, ou seja, o ponto crítico em que a mínima flutuação de energia pode conduzir a um novo estado, representa a potencialidade do sistema em ser atraído para um novo estado de menor entropia. Deste modo a irreversibilidade nos sistemas abertos significa que estes são produto da sua história (28).

A importância desta teoria está na nova concepção da matéria e da natureza que propōe, uma concepção dificilınente compaginável com a que herdámos da física clássica. Em vez da eternidade, a história; em vez do determinismo, a imprevisibilidade; em vez do mecanicismo, a interpenetração, a espontaneidade e a auto-organizaçāo; em vez da reversibilidade, a irreversibilidade e a evolução; em vez da ordem, a desordem; em vez da necessidade, a criatividade e o acidente. A teoria de Prigogine recupera inclusivamente conceitos aristotélicos tais como os conceitos de potencialidade e virtualidade que a revoluçāo científica do século XVI parecia ter atirado definitivamente nara o lixo da história.

Mas a importância maior desta teoria está em que ela não é um fenómeno isolado. Faz parte de um movimento conver-

(28) I. Prigogine e 1. Stengers, La Nouvelle Allianie. Metamurphose de la Science. Paris, Gallimard, 1979; I. Prigogine, From Being to Becoming. S. Francisco, Freeman, 1980; I. Prigogine, "Tïne, Irreversibility and Randomness", in E. Jantsch (org.), The Evolutionary Lision. Boulder, Westuiew Press, 1981, pp. 73 e ss. 
gente, pujante sobretudo a partir da última década, que atravessa as várias ciências da natureza e até as ciências sociais, um movimento de vocação transdisciplinar que Jantsch designa por paradigma da auto-organização e que tem afloraçōes, entre outras, na teoria de Prigogine, na sinergética de Haken (29), no conceito de hiperciclo e na teoria da origem da vida de Eigen (30), no conceito de autopoiesis de Maturana e Varela (31), na teoria das catástrofes de Thom (32), na teoria da evolução de Jantsch (33), na teoria da «ordem implicada» de David Bohm (34) ou na teoria da matriz-S de Geoffrey Chew e na filosofia do "bootstrap» que lhe subjaz (35). Este movimento científico e as demais inovaçōes teóricas que atrás defini como outras tantas condiçōes teóricas da crise do paradigma dominante

(29) H. Haken, Synergetics: An Introduction. Heidelberg, Springer 1977; H. Haken, "Synergetics - An Interdisciplinary Approach to Phenomena of Self-Organization", Geoforum, 16 (1985), 205.

(30) M. Eigen e P. Schuster, The Hypercycle: a Principle of Natural Self-Organization. Heidelberg, Springer, 1979.

(31) H. R. Maturana e F. Varela, De Maquinas y Seres Vivos. Santiago do Chile, Editorial Universitária, 1973; H. R. Maturana e F. Varela, Autopoietic Systems. Urbana, Biological Computer Laboratory University of Illinois, 1975. Cfr. também, F. Benseler, P. Hejl e W. Koch (orgs.), Autopoiesis. Communication and Society. The Theory of Autopoietic Systems in the Social Sciences. Frankfurt, Campus, 1980.

(32) R. Thom, ob. cit., pp. 85 e ss.

(33) E. Jantsch, The Self-Organizing Universe: Scientific and Human Implications of the Emerging Paradigm of Evolution. Oxford, Pergamon, 1980; E. Jantsch, "Unifying Principles of Evolution", in E. Jantsch (org.), 7 he Evolutionary Vision, cit., pp. 83 e ss.

(34) D. Bohm, Wholeness and the Implicate Order. Londres, Ark Paperbacks, 1984.

(35) G. Chew, «Bootstrap: a scientific idea?», Srience, 161 (1968), pp. 762 e ss; G. Chew, "Hardon bootsuap: triumph or frustration?», Physics Todav, 23 (1970), pp. 23 e ss; F. Capra, "Quark physics without quarks: $A$ review of recent developments in S-matrix theory", American Journal of Physics. 47 (1979), pp. 11 e ss. 
têm vindo a propiciar uma profunda reflexāo epistemológica sobre o conhecimento científico, uma reflexāo de tal modo rica e diversificada que, melhor do que qualquer outra circunstância, caracteriza exemplarmente a situaçāo intelectual do tempo presente. Esta reflexão apresenta duas facetas sociológicas importantes. Em primeiro lugar, a reflexāo é levada a cabo predominantemente pelos próprios cientistas, por cientistas que adquiriram uma competência e um interesse filosóficos para problematizar a sua prática científica. Nãoé arriscado dizer que nunca houve tantos cientistas-filósofos como actualmente, e isso não se deve a uma evolução arbitrária do interesse intelectual. Depois da euforia cientista do século XIX e da consequente aversāo à reflexāo filosófica, bem simbolizada pelo positivismo, chegámos a finais do século $\mathrm{XX}$ possuídos pelo desejo quase desesperado de complementarmos o conhecimento das coisas com o conhecimento do conhecimento das coisas, isto é, com o conhecimento de nós próprios. A segunda faceta desta reflexão é que ela abrange questōes que antes eram deixadas aos sociólogos. A análise das condiçōes sociais, dos contextos culturais, dos modelos organizacionais da investigaçāo científica, antes acantonada no campo separado e estanque da sociologia da ciência, passou a ocupar papel de relevo na reflexão epistemológica.

Do conteúdo desta reflexão respigarei, a título ilustrativo, alguns dos temas principais. Em primeiro lugar, são questionados o conceito de lei e o conceito de causalidade que the está associado. A formulação das leis da natureza funda-se na ideia de que os fenómenos observados independem de tudo excepto de um conjunto razoavelmente pequeno de condiçōes (as condiçōes iniciais) cuja interferência é observada e medida. Esta ideia, reconhece-se hoje, obriga a separaçóes grosseiras entre os fenómenos, separaçōes que, aliás, são sempre provi- 
sórias e precárias uma vez que a verificação da não interferência de certos factores é sempre produto de um conhecimento imperfeito, por mais perfeito que seja. As leis têm assim um carácter probabilístico, aproximativo e provisório, bem expresso no princípio da falsit cabilidade de Popper. Mas acima de tudo, a simplicidade das leis constitui uma simplificação arbitrária da realidade que nos confina a um horizonte mínimo para além do qual outros conhecimentos da natureza, provavelmente mais ricos e com mais interesse humano, ficam por conhecer. Na biologia, onde as interacçōes entre fenómenos e formas de auto-organizaçāo em totalidades nāo mecânicas são mais visíveis, mas também nas demais ciências, a noção de lei tem vindo a ser parcial e sucessivamente substituída pelas noções de sistema, de estrutura, de modelo e, por último, pela noçāo de processo. O declínio da hegemonia da legalidade é concomitante do declínio da hegemonia da causalidade. Oquestionamento da causalidade nos tempos modernos vem de longe, pelo menos desde David Hume e do positivismo lógico. A reflexão crítica tem incidido tanto no problema ontológico da causalidade (quais as características do nexo causal?; esse nexo existe na realidade?) como no problema metodológico da causalidade (quais os critérios de causalidade?; como reconhecer um nexo causal ou testar uma hipótese causal?). Ioje, a relativização do conceito de causa parte sobretudo do reconhecimento de que o lugar central que ele tem ocupado na ciência moderna se explica menos por razóes ontológicas ou metodológicas do que por razóes pragmáticas. O conceito de causalidade adequa-se bem a uma ciência que visa intervir no real e que mede o seu êxito pelo âmbito dessa intervenção. Afinal, causa é tudo aquilo sobre que se pode agir. Mesmo os defensores da causalidade, como Mario Bיnge, reconhecem que ela é apenas uma das formas do determinismo e que por isso 
tem um lugar limitado, ainda que insubstituível, no conhecimento científico (36). A verdade é que, sob a égide da biologia e também da microfísica, o causalismo, enquanto categoria de inteligibilidade do real, tem vindo a perder terreno em favor do finalismo.

O segundo grande tema de reflexão epistemológica versa mais sotre o conteúdo do conhecimento científico do que sobre a sua forma. Sendo um conhecimento mínimo que fecha as portas a muitos outros saberes sobre o mundo, o conhecimento científico moderno é um conhecimento desencantado e triste que transforma a natureza num autómato, ou, como diz Prigogine, num interlocutor terrivelmente estúpido (37). Este aviltamento da natureza acaba por aviltar o próprio cientista na medida em que reduz o suposto diálogo experimental ao exercício de uma prepotência sobre a natureza. O rigor científico, porque fundado no rigor matemático, é um rigor que quantifica e que, ao quantificar, desqualifica, um rigor que, ao objectivar os fenómenos, os objectualiza e os degrada, que, ao caracterizar os fenómenos, os caricaturiza. E, em suma c finalmente, uma forma de rigor que, ao afirmar a personalidade do cientista, destrói a personalidade da natureza. Nestes termos, o conhecimento ganha $\mathrm{em}$ rigor o que perde em riqueza e a retumbância dos êxitos da intervençāo tecnológica esconde os limites da nossa compreensão do mundo e reprime a pergunta

(36) M. Bunge, Causality and Modern Science. Nova Iorque, Dover Publications, 3' elição, 1979, p. 353: "The causal principle is, in short, neither a panacea nor a myth: it is a general hypothesis subsumed under the universal principle of determinacy, and having an approximate validity in its proper domain». Em Portugal é justo salientar neste dominio a notável obra teórica de Armando Castro. Cfr. Teoria do Conherimento Cientifico, vols. I-IV, Porto, Limiar, 1975, 1978, 1980, 1982; vol. V, Porto, Afrontamento, 1987.

(37) I. Prigogine e 1. Stengers, ob. cit., p. 13. 
pelo valor humano do afã científico assim concebido. Esta pergunta está, no entanto, inscrita na própria relação sujeito/objecto que preside à ciência moderna, uma relação que interioriza o sujeito à custa da exteriorização do objecto, tornando- os estanques e incomunicáv is.

Os limites deste tipo de conhecimento são, assim, qualitativos, não são superáveis com maiores quantidades de investigação ou maior precisão dos instrumentos. Aliás, a própria precisāo quantitativa do conhecimento é estruturalmente limitada. Por exemplo, no domínio das teorias da informaçāo o teorema de Brillouin demonstra que a informaçāo nāo é gratuita (38). Qualquer observação efectuada sobre um sistema físico aumenta a entropia do sistema no laboratório. O rendimento de uma dada experiência deve assim ser definido pela relação entre a informação obtida e o aumento concomitante da entropia. Ora, segundo Brillouin, esse rendimento é sempre inferior à unidade e só em casos raros é próximo dela. Nestes termos, a experiência rigorosa é irrealizável pois que exigiria um dispêndio infinito de actividades humanas. Por último, a precisāo é limitada porque, se é verdade que o conhecimento só sabe avançar pela via da progressiva parcelização do objecto, bem representada nas crescentes espe iializaçōes da ciência, é exactamente por essa via que melhor se confirma a irredutibilidade das totalidades orgânicas ou inorgânicas às partes que as constituem e, portanto, o carácter distorcivo do conhecimento centrado na observação destas últimas. Os factos observados têm vindo a escapar ao regime de isolamento prisional a que a ciência os sujeita. Os objectos têm fronteiras cada vez menos definidas; são constituídos por anéis que se

(38) L. Brilkouin, La Science el la Théoric de I'Information. Paris, Masson, 1959. Cf. também, Parain-Vial, ob. cit. pp. 122 c ss. 
entrecruzam em teias complexas com os dos restantes objectos, a tal ponto que os objectos em si são menos reais que as relaçōes entre eles.

Ficou dito no início desta parte que a crise do paradigma da ciência moderna se explica por condiçōes teóricas, que acabei ilustrativamente de apontar, e por condiçōes sociais. Estas últimas não podem ter aqui tratamento detalhado (39). Referirei tāo-só que, quaisquer que sejam os limites estruturais de rigor científico, não restam dúvidas que o que a ciência ganhou em rigor nos úitimos quarenta ou cinquenta anos perdeu em capacidade de auto-regulação. As ideias da autonomia da ciência e do desinteresse do conhecimento científico, que durante muito tempo constituiram a ideologia espontânea dos cientistas, colapsaram perante o fenómeno global da industrialização da ciência a partir sobretudo das décadas de trinta e quarenta. Tanto nas sociedades capitalistas como nas sociedades socialistas de Estado do leste europeu, a industrialização da ciência acarretou o compromisso desta com os centros de poder económico, social e político, os quais passaram a ter um papel decisivo na definição das prioridades científicas.

A industrialização da ciência manifestou-se tanto ao nível das aplicaçōes da ciência como ao nível da organizaçāo da investigação científica. Quanto às aplicaçōes, as bombas de Hiroshima e Nagasaki foram um sinal trágico, a princípio visto como acidental e fortuito, mas hoje, perante a catástrofe ecológica e o perigo do holocausto nuclear, cada vez mais visto como manifestaçāo de um modo de produçāo da ciência inclinado a transformar acidentes em ocorrências sistemáticas.

(39) Sobre este tema cfr. Boaventura de Sousa Santos. "Da SocioIogia da Ciência à Política Científican, Revista Crítica de Cienncias Soriais. 1 (1978), pp. 11 ess. 
"A ciência e a tecnologia têm vindo a revelar-se as duas faces de um processo histórico em que os interesses militares e os interesses económicos vão convergindo até quase à indistinçāo» (40). No domínio da orģanizaçāo do trabalho científico, a industrialização da ciência produziu dois efeitos principais. Por um lado, a comunidade cient fica estratificou-se, as relaçōes de poder entre cientistas tomaram-se mais autoritárias e desiguais e a esmagadora maioria dos cientistas foi submetida a um processo de proletarização no interior dos laboratórios e dos centros de investigação. Por outro lado, a investigação capital- intensiva (assente em instrumentos caros e raros) tomou impossível o livre acesso ao equipamento, o que contribuiu para o aprofundamento do fosso, em termos de desenvolvimento científico e tecnológico, entre os países centrais e os países periféricos.

Pautada pelas condiçōes teóricas e sociais que acabei de referir, a crise do paradigma da ciência moderna nāo constitui um pântano cinzento de cepticismo ou de irracionalismo. É antes o retrato de uma família intelectual numerosa e instável, mas também criativa e fascinante, no momento de se despedir, com alguma dor, dos lugares conceituais, teóricos e epistemológicos, ancestrais e íntimos, mas não mais convincentes e securizantes, uma despedida em busca de uma vida melhor a caminho doutras paragens onde o optimismo seja mais fundado e a racionalidade mais plural e onde finalmente o conhecimento volte a ser uma aventura encantada. A caracterizaçáo da crise do paradigma dominante traz consigo o perfil do paradigma emergente. E esse o perfil que procurarei desenhar a seguir.

(40) Boaventura de Sousa Santos, ob. cit., p. 26. 


\section{O PARADIGMA EMERGENTE}

A configuraçāo do paradigma que se anuncia no horizonte só pode obter-se por via especulativa. Uma especulação fundada nos sinais que a crise do paradigma actual emite mas nunca por eles determinada. Aliás, como diz René Poirier e antes dele disseram Hegel e Heidegger, «a coerência global das nossas verdades físicas e metafísicas só se conhece retrospectivamente» (41). Por isso, ao falarmos do futuro, mesmo que seja de um futuro que já nos sentimos a percorrer, o que dele dissermos é sempre o produto de uma sintese pessoal embebida na imaginação, no meu caso na imaginação sociológica. Não espanta, pois, que ainda que com alguns pontos de convergência, sejam diferentes as sínteses até agora apresentadas. Ilya Prigogine, por exemplo, fala da "nova aliança» e da metamorfose da ciência ${ }^{(42)}$. Fritjof Capra fala da "nova física" e do Taoismo da física (43), Eugene Wigner de «mudanças do segundo tipo" (44), Erich Jantsch do paradigma da auto-organização (45), Daniel Bell da sociedade pós-industrial (46), I Habermas da sociedade comunicativa ${ }^{(47)}$. Eu falarei, por ago-

(41) R. Poirier, prefácio a Parain-Vial, ob. cit., p. 10.

(42) I. Prigogine, obs. cits.

(43) F. Capra, The Tan of Physics. Nova Iorque, Bantam Books, (1976), 1984; 1: Capra, The Turning Point. Nova lorque, Bantam Books, 1983.

(44) E. Wigner, $o b$. cit, pp. 215 e ss.

(45) E. Jantsch, obs. cits.

(46) D. Bell, The Coming Crisis of Post-Industrial Sorcets. Noval Iorque, Basic B(x)ks, 1976.

(47) J. Habermas, Thoorie des Komununikativen Mandelns, 2 vols. Frankfurt, Suhrkamp. 1982. 
ra, do paradigma de um conhecimento prudente para uma vida decente. Com esta designação quero significar que a natureza da revolução científica que atravessamos é estruturalmente diferente da que ocorreu no si culo XVI. Sendo uma revolução científica que ocorre numa sr ciedade ela própria revolucionada pela ciência, o paradigma a emergir dela não pode ser apenas um paradigma científico (o paradigma de um conhecimento prudente), tem de ser também um paradigma social (o paradigma de uma vida decente). Apresentarei o paradigma emergente através de um conjunto de teses seguidas de justificaçāo.

\section{Todo o conhecimento científico-natural é científico-social}

A distinção dicotómica entre ciências naturais e ciências sociais deixou de ter sentido e utilidade. Esta distinção assenta numa concepção mecanicista da matéria e da natureza a que contrapõe, com pressuposta evidência, os conceitos de ser humano, cultura e sociedade. Os avanços recentes da física e da biologia pōem em causa a distinção entre o orgânico e o inorgânico, entre seres vivos e matéria inerte e mesmo entre o humano e o não humano. As características da auto-organizaçāo, do metabolismo e da auto-reprodução, antes consideradas específicas dos seres vivos, são hoje atribuídas aos sistemas pré-celulares de moléculas. E quer num quer noutros reconhecem-se propriedades e comportamentos antes considerados específicos dos seres humanos e das relações sociais. $A$ teoria das estruturas dissipativas de Prigogine, ou a teoria sinergética de Haken já citadas, mas também a teoria da «ordem implicada" de David Bohm, a teoria da matriz-S de Geoffrey Chew e a fi- 
losofia do «bootstrap» que lhe subjaz e ainda a teoria do encontro entre a física contemporânea e o misticismo oriental de Fritjof Capra, todas elas de vocação holística e algumas especificamente orientadas para superar as inconsistências entre a mecânica quântica e a teoria da relatividade de Einstein, todas estas teorias introduzem na matéria os conceitos de historicidade e de processo, de liberdade, de auto-determinação e até de consciência que antes o homem e a mulher tinham reservado para si. É como se o homem e a mulher se tivessem lançado na aventura de conhecer os objectos mais distantes e diferentes de si próprios, para, uma vez aí chegados, se descobrirem reflectidos como num espelho. Já no princípio da década de sessenta e extrapolando a partir da mecânica quântica, Eugene Wigner considerava que o inanimado nāo era uma qualidade diferente mas apenas um caso limite, que a distinção corpo/alma deixara de ter sentido e que a física e a psicologia acabarriam por sc fundir numa única ciência (48). Hoje é possível ir muito além da mecânica quântica. Enquanto esta introduziu a consciência no acto do conhecimento, nós temos hoje de a introduzir no próprio objecto do conhecimento, sabendo que, com isso, a distinção sujeito/objecto sofrerá uma transformaçäo radical. Num certo regresso ao pan-psiquismo leibniziano, começa hoje a reconhecer-se uma dimensāo psíquica na natureza, "a mente mais ampla» de que fala Bateson, da qual a mente humana é apenas uma parte, uma mente imanente ao sistema social global e à ecologia planetária que alguns chamam Deus ${ }^{(49)}$. Geoffrey Chew postula a existência de consciência na natureza como um elemento necessário à auto-consistência desta última e, se assim for, as futuras

(48) E. Wigner, ob. cil, p. 271.

(.19) G. Bateson. Mind and Naure. Londres, Fontana, 1985. 
teorias da matéria terão de incluir o estudo da consciência humana. Convergentemente, assiste-se a um renovado interesse pelo "inconsciente colectivo", imanente à humanidade no seu todo, de Jung. Aliás, Capri: pretende ver as ideias de Jung sobretudo a ideia da sincıonicidade para explicar a relação entre a realidade exterior e a realidade interior - confirmadas pelos recentes conceitos de interacçōes locais e não locais na física das partículas (50). Tal como na sincronia jungiana, as interacçūes não locais são instantâneas e não podem ser previstas em termos matemáticos precisos. Nāo sāo, pois, produzidas por causas locais e, quando muito, poder-se-á falar da causalidade estatística. Capra vê em Jung uma das alternativas teóricas às concepçōes mecanicistas de Freud e Bateson afirma que enquanto Freud ampliou o conceito de mente para dentro (permitindo-nos abranger o subconsciente e o inconsciente) é necessário agora ampliá-lo para fora (reconhecendo a existência de fenómenos mentais para além dos individuais e humanos). Semelhantemente, a teoria da «ordem implicada», que, segundo o seu autor, David Bohm, pode constituir uma base comum tanto à teoria quântica como à teoria da relatividade, concebe a consciência e a matéria como interdependentes sem, no entanto, estarem ligadas por nexo de causalidade. Sāo antes duas projeç̧óes, mutuamente envolventes, de uma realidade mais alta que não é nem matéria nem consciência. O conhecimento do paradigma emergente tende assim a ser um conhecimento nāo dualista, um conhecimento que se funda na superaçāo das distinçōes tāo familiares e óbvias que até há pouco considerávamos insubstituiveis, tais como natureza/cultura, natural/artificial, vivo/inanimado, mente/matéria, observador/ob-

(50) Cfr. Lambén M. Bowen, "The Ecology of Knowledge: Linking the Natural and Social Sciences", Geoforum, 16 (1985), pp. 213 c ss. 
servado, subjectivo/objectivo, colectivo/individual, animal/pessoa. Este relativo colapsö das distinçóes dicotómicàsrepercute- se nas disciplinas científicas que sobre elas se fundaram. Aliás, sempre houve ciências que se reconheceram mal nestas distinçōes e tanto que se tiveram de fracturar internamente para se lhes adequarem minimamente. Refiro-me à antropologia, à geografia e tambémà psicologia. Condensaram-se nelas privilegiadamente as contradiçōes da separação ciências naturais/ciências sociais. Daí que, num período de transiçāo entre paradigmas, seja particularmente importante, do ponto de vista epistemológico, observar o que se passa nessas ciências.

Nāo basta, porém, apontar a tendência para a superação da distinção entre ciências naturais e ciências sociais, é preciso conhecer o sentido e conteúdo dessa superação. Recorrendo de novo à física, trata-se de saber qual será o "parâmetro de ordem», segundo Haken, ou o «atractor», segundo Prigogine, dessa superação, se as ciências naturais, se as ciências sociais. Precisamente porque vivemos um estado de turbulência, as vibraçóes do novo paradigma repercutem-se desigualmente nas várias regiōes do paradigma vigente e por isso os sinais do futuro são ambíguos. Alguns lêem neles a emergência de um novo naturalismo centrado no privilegiamento dos pressupostos biológicos do comportamento humano. Assim Konrad Lorenz ou a sociobiologia. Para estes, a superaçāo da dicotomia ciências naturais/ciências sociais ocorre sob a égide das ciências naturais. Contra esta posição pode objectar-se q'e ela tem do futuro a mesma concepçāo com que as ciências naturais auto-justificam, no seio do paradigma dominante, o seu prestígio científico, social e político e, por isso, só vê do futuro aquilo em que ele repete o presente. Se, pelo contrário, numa reflexāo mais aprofundada, atentarmos no conteúdo teórico das ciências que mais têm progredido no conhecimento da 
matéria, verificamos que a emergente inteligibilidade da natureza é presidida por conceitos, teorias, metáforas e analogias das ciências sociais. Para nāo irmos mais longe, quer a teoria das estruturas dissipativas de Prigogine quer a teoria sinergética de Haken explicam o comportamento das partículas através dos conceitos de revolução social, violência, escravatura, dominação, democracia nuclear, todos eles originários das ciências sociais (da sociologia, da ciência política, da história, etc.). O mesmo sucede, ainda no campo da física teórica, com as teorias de Capra sobre a relaçāo entre física e psicanálise, os padrōes da matéria e os padrōes da mente concebidos como reflexos uns dos outros. Apesar de estas teorias diluirem as fronteiras entre os objectos da física e os objectos da biologia, foi sem dúvida no domínio desta última que os modelos explicativos das ciências soc'ais mais se enraizaram nas décadas recentes. Os conceitos de teleomorfismo, autopoiesis, auto-organizaçāo, potencialidade organizada, originalidade, individualidade, historicidade, atribuem à natureza um comportamento humano. Lovelock, em livro recente sobre as ciências da vida, afirma que os nossos corpos são constituídos por cooperativas de células (51).

Que os modelos explicativos das ciências sociais vêm subjazendo ao desenvolvimento das ciências naturais nas últimas décadas prova-se, além do mais, pela facilidade com que as teorias físico-naturais, uma vez formuladas no seu domínio específico, se aplicam ou aspiram aplicar-se no domínio social. Assim, por exemplo, Peter Allen, um dos mais estreitos colaboradores de Prigogine, tem vindo a aplicar a teoria das estruturas dissipativas aos processos económicos e à evolução

(51) J. E. Lovelock, Gaia: a New Look at Life on Earth. Oxford, Oxford University Press. 
das cidades e das regiōes (52). E Haken salienta as potencialidades da sinergética para explicar situaçōes revolucionárias na sociedade (53). É como se o dito de Durkheim se tivesse invertido e em vez de serem os fenómenos sociais a ser estudados como se fossem fenómenos naturais, serem os fenómenos naturais estudados como se fossem fenómenos sociais.

$\mathrm{O}$ facto de a superação da dicotomia ciências naturais/ /ciências sociais ocorrer sob a égide das ciências sociais não é, contudo, suficiente para caracterizar o modelo de conhecimento no paradigma emergente. É que, como disse atrás, as próprias ciências sociais constituiram-se no século XIX segundo os modelos de racionalidade das ciências naturais clássicas e, assim, a égide das ciências sociais, afirmada sem mais, pode revelar-se ilusória. Referi contudo que a constituiçāo das ciências sociais teve lugar segundo duas vertentes: uma mais directamente vinculada à epistemologia e à metodologia positivistas das ciências naturais, e outra, de vocação anti-positivista, caldeada numa tradiçāo filosófica complexa, fenomenológica, interaccionista, mito-simbólica, hermenêutica, existencialista, pragmática, reivindicando a especificidade do estudo da sociedade mas tendo de, para isso, pressupor uma concepção mecanicista da natureza. A pujança desta segunda vertente nas duas últimas décadas é indicativa de ser ela o modelo de ciências sociais que, numa época de revolução científica, transporta a marca pós-moderna do paradigma emergente. Trata-se, como referi também, de um modelo de transição, uma vez que define a especificidade do humano por contraposição a uma concepção da natureza que as ciências natu-

(52) P. Allen, «The Evolutionary Paradigm of Dissipative Structures», in E. Jantsch (org.), The Evolutionary Vision, cit., pp. 25 e ss.

(53) H. Haken, «Synergetics - An Interdisciplinary Approach to Phenomena of Self-organization", cit., pp. 205 e ss. 
rais hoje consideram ultrapassada, mas é um modelo em que aquilo que o prende ao passado é menos forte do que aquilo que o prende ao futuro. Em resumo, à medida que as ciências naturais se aproximam das ciências sociais estas aproximam-se das humanidades. O sujeito, que a ciência moderna lançara na diáspora do conhecimento irracional, regressa investido da tarefa de fazer erguer sobre si uma nova ordem científica.

Que este é o sentido global da revoluçāo científica que vivemos, é também sugerido pela reconceptualização em curso das condiçōes epistemológicas e metodológicas do conhecimento científico social. Referi acima alguns dos obstáculos à cientificidade das ciências sociais, os quais, segundo o paradigma ainda dominante, seriam responsáveis pelo atraso das ciências sociais em relação às ciências naturais. Sucede contudo que, também como referi, o avanço do conhecimento das ciências naturais e a reflexāo epistemológica que ele tem suscitado têm vindo a mostrar que os obstáculos ao conhecimento científico da sociedade e da cultura sāo de facto condiçōes do conhecimento em geral, tanto científico-social como científico-natural. Ou seja, o que antes era a causa do maior atraso das ciências sociais é hoje o resultado do maior avanço das ciências naturais. Daí também que a concepçāo de Thomas Kuhn sobre o carácter pré-paradigmático (isto é, menos desenvolvido) das ciências sociais ${ }^{(54)}$, que eu, aliás, subscrevi e reformulei noutros escritos (55), tenha de ser abandonada ou profundamente revista.

A superação da dicotomia ciências naturais/ciências sociais tende assim a revalorizar os estudos humanísticos. Mas esta

(54) T. Kuhn, The Structure of Scientific Revolutions. Chicago, University of Chicago Press, 1962, passim.

(55) Boaventura de Sousa Santos, ob. cit., pp. 29 e ss. 
revalorização não ocorrerá sem que as humanidades sejam, elas também, profundamente transformadas. O que há nelas de futuro é o terem resistido à separação sujeito/objecto e o terem preferido a compreensão do mundo à manipulaçáo do mundo. Este núcleo genuíno foi, no entanto, envolvido num anel de preocupaçōes mistificatórias (o esoterismo nefelibata e a erudição balofa). O ghetto a que as humanidades se remeteram foi em parte uma estratégia defensiva contra o assédio das ciências sociais, armadas do viés cientista triunfalmente brandido. Mas foi também o produto do esvaziamento que sofreram em face da ocupação do seu espaço pelo modelo cientista. Foi assim nos estudos históricos com a história quantitativa, nos estudos jurídicos com a ciência pura do direito e a dogmática jurídica, nos estudos filológicos, literários e linguísticos com o estruturalismo. Há que recuperar esse núcleo genuíno e pô-lo ao serviço de uma reflexăo global sobre o mundo. $\mathrm{O}$ texto sobre que sempre se debruçou a filologia é uma das analogias matriciais com que se construirá no paradigma emergente o conhecimento sobre a sociedade e a natureza.

A concepção humanística das ciências sociais enquanto agente catalisador da progressiva fusão das ciências naturais e ciências sociais coloca a pessoa, enquanto autor e sujeito do mundo, no centro do conhecimento, mas, ao contrário das humanidades tradicionais, coloca o que hoje designamos por natureza no centro da pessoa. Näo há natureza humana porque toda a natureza é humana. É pois necessário descobrir categorias de inteligibilidade globais, conceitos quentes que derretam as fronteiras em que a ciência moderna dividiu e encerrou a realidade. A ciência pós-moderna é uma ciência assumidamente analógica que conhece o que conhece pior através do que conhece melhor. Já mencionei a analogia textual e julgo que tanto a analogia lúdica como a analogia dramática, como ainda a ana- 
logia biográfica, figurarão entre as categorias matriciais do paradigma emergente: o mundo, que hoje é natural ou social e amanhã será ambos, visto como um texto, como um jogo, como um palco ou ainda como uma autobiografia. Clifford Geertz refere algumas destas analogias humanísticas e restringe o seu uso às ciências sociais, enquanto eu as concebo como categorias de inteligibilidade universais (56). Não virá longe o dia em que a física das partículas nos fale do jogo entre as partículas, ou a biologia nos fale do teatro molecular ou a astrofísica do tex to celestial, ou ainda a química da biografia das reacçóes químicas. Cada uma destas analogias desvela uma ponta do mundo. A nudez total, que será sempre a de quem se vê no que vê, resultará das configuraçōes de analogias que soubermos imaginar: afinal, o jogo pressupōe um palco, o palco exercita-se com um texto e o texto é a autobiografia do seu autor. Jogo, palco, tex to ou biografia, o mundo é comunicação e por isso a lógica existencial da ciência pós-moderna é promover a "situação comunicativa» tal como Habermas a concebe. Nessa situação confluem sentidos e constelações de sentido vindos, tal qual rios, das nascentes das nossas práticas locais e arrastando consigo as areias dos nossos percursos moleculares, individuais, comunitários, sociais e planetários. Não se trata de uma amálgama de sentido (que não seria sentido mas ruído), mas antes de interaç̧ōes e de intertextualidades organizadas em torno de projectos locais de conhecimento indiviso. Daqui decorre a segunda característica do conhecimento científico pós-moderno.

(56) C. Geertz, Local Knowledge. Further Essays in Interpretative Anthropology. Nova lorque, Basic Books, 1983, pp. 19 e ss. 


\section{Todo o conhecimento é local e total}

$\mathrm{Na}$ ciência moderna o conhecimento avança pela especialização. O conhecimento é tanto mais rigoroso quanto mais restrito é o objecto sobre que incide. Nisso reside, aliás, o que hoje se reconhece ser o dilema básico da ciência moderna: o seu rigor aumenta na proporçáo directa da arbitrariedade com que espartilha o real. Sendo um conhecimento disciplinar, tende a ser um conhecimento disciplinado, isto é, segrega uma organizaçāo do saber orientada para policiar as fronteiras entre as disciplinas e reprimir os que as quiserem transpor. É hoje reconhecido que a excessiva parcelizaçāo e disciplinarização do saber científico faz do cientista um ignorante especializado e que isso acarreta efeitos negativos. Esses efeitos são sobretudo visíveis no domínio das ciências aplicadas. As tecnologias preocupam-se hoje com o seu impacto destrutivo nos eco-sistemas; a medicina verifica que a hiper-especialização do saber médico transformou o doente numa quadrícula sem sentido quando, de facto, nunca estamos doentes senão em geral; a farmácia descobre o lado destrutivo dos medicamentos, tanto mais destrutivos quanto mais específicos, e procura uma nova lógica de combinaçāo química atenta aos equilíbrios orgânicos; o direito, que reduziu a complexidade da vida jurídica à secura da dogmática, redescobre o mundo filosófico e sociológico em busca da prudência perdida; a economia, que legitimara o reducionisme quantitativo e tecnocrático com o pretendido êxito das previsōes económicas, é forçada a reconhecer, perante a pobreza dos resultados, que a qualidade humana e sociológica dos agentes e processos económicos entra pela janela depois de ter sido expulsa pela porta; para grangear o reconhecimento dos utentes (que, públicos ou privados, institucionais ou indi- 
viduais, sempre estiveram numa posiçāo de poder em relação aos analisados) a psicologia aplicada privilegiou instrumentos expeditos e facilmente manuseáveis, como sejam os testes, que reduziram a riqueza da personalidade às exigências funcionais de instituiçōes unidimensionai..

Os males desta parcelização do conhecimento e do reducionismo arbitrário que transporta consigo são hoje reconhecidos, mas as medidas propostas para os corrigir acabam em geral por os reproduzir sob outra forma. Criam-se novas disciplinas para resolver os problemas produzidos pelas antigas e por essa via reproduz-se o mesmo modelo de cientificidade. Apenas para dar um exemplo, o médico generalista, cuja ressurreição visou compensar a hiper-especializaçāo médica, corre o risco de ser convertido num especialista ao lado dos demais. Este efeito perverso revela que nāo há solução para este problema no seio do paradigma dominante e precisamente porque este último é que constitui o verdadeiro problema de que decorrem todos os outros.

No paradigma emergente o conhecimento é total, tem como horizonte a totalidade universal de que fala Wigner ou a totalidade indivisa de que fala Bohm. Mas sendo total, é também local. Constitui-se em redor de temas que em dado momento sāo adoptados por grupos sociais concretos como projectos de vida locais, sejam eles reconstituir a história de um lugar, manter um espaço verde, construir um computador adequado às necessidades locais, fazer baixar a taxa de mortalidade infantil, inventar um novo instrumento musical, erradicar uma doença, etc., etc.. $\Lambda$ fragmentaçāo pós-moderna nāo é disciplinar e sim temática. Os temas são galerias por onde os conhecimentos progridem ao encontro uns dos outros. Ao contrário do que sucede no paradigma actual, o conhecimento avança à medida que o seu objecto se amplia, ampliaçāo que, como a da árvore. 
procede pela diferenciaçāo e pelo alastramento das raízes em busca de novas e mais variadas interfaces.

Mas sendo local, o conhecimento pós-moderno é também total porque reconstitui os projectos cognitivos locais, salientando-lhes a sua exemplaridade, e por essa via transforma-os em pensamento total ilustrado. A ciência do paradigma emergente, sendo, como deixei dito acima, assumidamente analógica, é também assumidamente tradutora, ou seja, incentiva os conceitos e as teorias desenvolvidos localmente a emigrarem para outros lugares cognitivos, de modo a poderem ser utilizados fora do seu contex to de origem. Este procedimento, que é reprimido por uma forma de conhecimento que concebe através da operacionalizaçăo e generaliza através da quantidade e da uniformização, será normal numa forma de conhecimento que concebe através da imaginação e generaliza através da qualidade e da exemplaridade.

O conhecimento pós-moderno, sendo total, não é determinístico, sendo local, não é descritivista. É um conhecimento sobre as condiçōes de possibilidade. As condiçōes de possibilidade da acçāo humana projectada no mundo a partir de um espaço-tempo local. Um conhecimento deste tipo é relativamente imetódico, constitui-se a partir de uma pluralidade metodológica. Cada método é uma linguagem e a realidade responde na língua em que é perguntada. Só uma constelaçāo de métodos pode captar o silêncio que persiste entre cada língua que pergunta. Numa fase de revolução científica como a que atravessamos, essa pluralidade de métodos só é possível mediante transgressāo metodológica (57). Sendo certo que cada método só esclarece o que the convém e quando esclarece fá-lo sem

(57) Sobre o conceito de transgressão metodológica cfr. Boaventura de Sousa Santos, "Science and Politics: Doing Research in Rio's Squalter Setllements", in R. Luckham (org.). Law and Social Enquary: Case Sut- 
surpresas de maior, a inovação científica consiste em inventar contextos persuasivos que conduzam à aplicação dos métodos fora do seu habitat natural. Dado que a aproximação entre ciências naturais e ciências sociais se fará no sentido destas últimas, caberá especular se é possível, por exemplo, fazer a análise filológica de um traçado urbano, entrevistar um pássaro ou fazer observaçāo participante entre computadores.

A transgressāo metodológica reperc:ite-se nos estilos e géneros literários que presidem à escrita científica. A ciência pós- moderna não segue um estilo unidimensional, facilmente identificável; o seu estilo é uma configuração de estilos construída segundo o critério e a imaginaçāo pessoal do cientista. A tolerância discursiva é o outro lado da pluralidade metodológica. $\mathrm{Na}$ fase de transiçāo em que nos encontramos são já visíveis fortes sinais deste processo de fusāo de estilos, de interpenetraçōes entre cânones de escrita. Clifford Geertz estuda o fenómeno nas ciências sociais e apresenta alguns exemplos: invesligação filosófica parecendo crítica literária no estudo de Sartre sobre Flaubert; fantasias barrocas sob a forma de observaçōes empíricas (a obra de Jorge Luis Borges); parábolas apresentadas como investigações etnográficas (Carlos Castañeda); estudos epistemológicos sob a forma de textos políticos (a obra Against Method de Paul Feyerabend) (58). E como Geertz, podemos perguntar se Foucault é historiador, filósofo, sociólogo ou cientista político. A composição transdisciplinar e individualizada para que estes exemplos apontam sugere um movimento no sentido da maior personalização do trabalho científico. Isto conduz à terceira característica do conhecimento científico no paradigma emergente.

dies of Research. Uppsala. Scandinavian Institute of African Studies, 1981, pp. 275 e ss.

(58) C. Geertz, oh. cit., p. 20. 


\section{Todo o conhecimento é auto-conhecimento}

A ciência moderna consagrou o homem enquanto sujeito epistémico mas expulsou-o, tal como a Deus, enquanto sujeito empírico. Um conhecimento objectivo, factual e rigoroso não tolerava a interferência dos valores humanos ou religiosos. Foi nesta base que se construiu a distinção dicotómica sujeito/objecto. No eatanto, a distinção sujeito/objecto nunca foi tāo pacífica nas ciências sociais quanto nas ciências naturais e a isso mesmo se atribuiu, como disse, o maior atraso das primeiras em relação às segundas. Afinal, os objectos de estudo eram homens e mulheres como aqueles que os estudavam. A distinção epistemológica entre sujeito e objecto teve de se articular metodologicamente com a distância empírica entre sujeito e objecto. Isto mesmo se torna evidente se compararmos as estratégias metodológicas da antropologia cultural e social, por um lado, e da sociologia, por outro. Na antropologia, a distância empírica entre o sujeito e o objecto era enorme. O sujeito era o antropólogo, o europeu civilizado, o objecto era o povo primitivo ou selvagem. Neste caso, a distinçāo sujeito/objecto aceitou ou mesmo exigiu que a distância fosse relativamente encurtada através do uso de metodologias que obrigavam a uma maior intimidade com o objecto, ou seja, o trabalho de campo etnográfico, a observação participante. Na sociologia, ao contrário, era pequena ou mesmo nula a distância empírica entre o sujeito e objecto: eram cientistas europeus a estudar os seus concidadāos. Neste caso, a distinção epistemológica obrigou a que esta distância fosse aumentada através do uso de metodologias de distanciamento: por exemplo, o inquérito sociológico, a análise dbcumental e a entrevista estruturada.

$A$ antropologia, entre a descolonizaçāo do pós-guerra e a 
guerra do Vietname, e a sociologia, a partir do final dos anos sessenta, foram levadas a questionar este status quo metodológico e as noções de distância social em que ele assentava. De repente, os selvagens foram vistos dentro de nós, nas nossas sociedades, e a sociologia passou a utilizar com mais intensidade métodos anteriormente quase monopolizados pela antropologia (a observação participante), ao mesmo tempo que nesta última os objectos passavam a ser concidadāos, membros de pleno direito da Organizaçāo das Naçóes Unidas, e tinham de ser estudados segundo métodos sociológicos. As vibrações destes movimentos na distinçāo sujeito/objecto nas ciências sociais vieram a explodir no periodo pós-estruturalista.

No domínio das ciências físico-naturais, o regresso do sujeito fora já anunciado pela mecânica quântica ao demonstrar que o acto de conhecimento e o produ to do conhecimento eram inseparáveis. Os avanços da microfísica, da astrofísica e da biologia das últimas décadas restituíram à natureza as propriedades de que a ciência moderna a expropriara. $O$ aprofundamento do conhecimento conduzido segundo a matriz materialista veio a desembocar num conhecimento idealista. A nova dignidade da natureza mais se consolidou quando se verificou que o desenvolvimento tecnológico desordenado nos tinha separado da natureza em vez de nos unir a ela e que a exploração da natureza tinha sido o veículo da exploração do homem. $\mathrm{O}$ desconforto que a distinçāo sujeito/objecto sempre tinha provocado nas ciências sociais propagava-se assim às ciências naturais. O sujeito regressava na veste do objecto. Aliás, os conceitos de «mente imanente», «mente mais ampla» e «mente colectiva» de Bateson e outros constituem notícias dispersas de que o outro foragido da ciência moderna, Deus, pode estar em vias de regressar. Regressará transfigurado, sem nada de divino senāo o nosso desejo de harmonia e comunhão com tudo o 
que nos rodeia e que, vemos agora, é o mais íntimo de nós. Uma nova gnose está em gestação.

Parafraseando Clausewitz, podemos afirmar hoje que o objecto é a continuação do sujeito por outros meios. Por isso, todo o conhecimento científico é auto-conhecimento. A ciência não descobre, cria, e o acto criativo protagonizado por cada cientista e pela comunidade científica no seu conjunto tem de se conhecer intimamente antes que conheça o que com ele se conhece do real. Os pressupostos metafísicos, os sistemas de crenças, os juízos de valor não estão antes nem depois da explicação científica da natureza ou da sociedade. Sāo parte integrante dessa mesma explicaçāo. A ciência moderna não é a única explicação possível da realidade e não há sequer qualquer razão científica para a considerar melhor que as explicaçōes alternativas da metafísica, da astrologia, da religião, da arte ou da poesia. $\wedge$ razão por que privilegiamos hoje uma forma de conhecimento assente na previsão e no controlo dos fenómenos nada tem de científico. É um juízo de valor. A explicação científica dos fenómenos é a auto-justificação da ciência enquanto fenómeno central da nossa contemporaneidade. A ciência é, assim, autobiográfica.

A consagração da ciência moderna nestes últimos quatrocentos anos naturalizou a explicaçāo do real, a ponto de nāo o podermos conceber senão nos termos por ela propostos. Sem as categorias de espaço, tempo, matéria e número - as metáforas cardeais da física moderna, segundo Roger Jones sentimo-nos incapazes de pensar, mesmo sendo já hoje capazes de as pensarmos como categorias convencionais, arbitrárias, metafóricas. Este processo de naturalização foi lento e, no início, os protagonistas da revoluçāo científica tiveram a noçāo clara que a prova íntima das suas conviçōes pessoais precedia e dava coerência às provas externas que desen- 
volviam. Descartes mostra melhor que ninguém o carácter autobiográfico da ciência. Diz, no Discurso do Método: "Gostaria de mostrar, neste Discurso, que caminhos segui; e de nele representar a minha vida como num quadro, para que cada qual a possa julgar, e para que, sabedor das opiniōes que sobre ele foram expendidas, um novo meio de me instruir se venha juntar àqueles de que costumo servir-me» (59). Hoje sabemos ou suspeitamos que as nossas trajectórias de vida pessoais e colectivas (enquanto comunidades científicas) e os valores, as crenças e os prejuízos que transportam são a prova íntima do nosso conhecimento, sem o qual as nossas investigaçōes laboratoriais ou de arquivo, os nossos cálculos ou os nossos trabalhos de campo constituiriam um emaranhado de diligências absurdas sem fio nem pavio. No entanto, este saber, suspeitado ou insuspeitado, corre hoje subterraneamente, clandestinamente, nos nāo-ditos dos nossos trabalhos científicos.

No paradigma emergente, o carácter autobiográfico e auto- referenciável da ciência é plenamente assumido. A ciência moderna legou-nos um conhecimento funcional do mundo que alargou extraordinariamente as nossas ferspectivas de sobrevivência. Hoje não se trata tanto de sobreviver como de saber viver. Para isso é necessária uma outra forma de conhecimento, um conhecimento compreensivo e íntimo que nāo nos separe e antes nos una pessoalmente ao que estudamos. A incerteza do conhecimento, que a ciência moderna sempre viu como limitação técnica destinada a sucessivas superações, transforma-se na chave do entendimento de um mundo que mais do que controlado tem de ser contemplado. Náo se trata do espanto medieval perante uma realidade hostil possuída do

(59) Descartes, ob. cil. p. 6. 
sopro da divindade, mas antes da prudência perante um mundo que, apesar de domesticado, nos mostra cada dia a precaridade do sentido da nossa vida por mais segura que esteja ao nível da sobrevivência. A ciência do paradigma emergente é mais contemplativa do que activa. A qualidade do conhecimento afere- se menos pelo que ele controla ou faz funcionar no mundo exterior do que pela satisfação pessoal que dá a quem a ele acede e o partilha.

A dimensão estética da ciência tem sido reconhecida por cientistas e filósofos da ciência, de Poincaré a Kuhn, de Polanyi a Popper. Roger Jones considera que o sistema de Newton é tanto uma obra de arte como uma obra de ciência ${ }^{(60)}$. A criação científica no paradigma emergente assume-se como próxima da criação literária ou artística, porque à semelhança destas pretende que a dimensão activa da transformação do real (o escultor a trabalhar a pedra) seja subordinada à contemplaçāo do resultado (a obra de arte). Por sua vez, o discurso científico aproximar-se-á cada vez mais do discurso da crítica literária. De algum modo, a crítica literária anuncia a subversāo da relação sujeito/objecto que o paradigma emergente pretende operar. Na crítica literária, o objecto do estudo, como se diria em termos científicos, sempre foi, de facto, um super-sujeito (um poeta, un romancista, um dramaturgo) face ao qual o crítico não passa de um sujeito ou autor secundário. É certo que, em tempos recentes, o crítico tem tentado sobressair no confronto com o escritor estudado a ponto de se poder falar de uma batalha pela supremacia travada entre ambos. Mas porque se trata de uma batalha, a relação é entre dois sujeitos e não entre um sujeito e um objecto. Cada um é a tradução do outro, ambos criadores de textos, escritos em línguas distintas ambas co-

(60) R. Jones, nh. cit, p. 11. 
nhecidas e necessárias para aprender a gostar das palavras e do mundo.

Assim ressubjectivado, o conhecimento científico ensina a viver e traduz-se num saber prático. Daí a quarta e última característica da ciência pós-moderna.

\section{Todo o conheciment o científico visa constituir-se em senso comum}

Já tive ocasião de referir que o fundamento do estatuto privilegiado da racionalidade científica não é em si mesmo científico. Sabemos hoje que a ciência moderna nos ensina pouco sobre a nossa maneira de estar no mundo e que esse pouco, por mais que se amplie, será sempre exíguo porque a exiguidade está inscrita na forma de conhecimento que ele constitui. A ciência moderna produz conhecimentos e desconhecimentos. $\mathrm{Se}$ faz do cientista um ignorante especializado faz do cidadão comum um ignorante generalizado.

Ao contrário, a ciência pós-moderna sabe que nenhuma forma de conhecimento é, em si mesma, racional; só a configuração de todas elas é racional. Tenta, pois, dialogar com outras formas de conhecimento deixando-se penetrar por elas. A mais importante de todas é o conhecimento do senso comum, o conhecimento vulgar e prático com que no quotidiano orientamos as nossas acçōes e damos sentido à nossa vida. A ciência moderna construiu-se contra o senso comum que considerou superficial, ilusório e falso. $\Lambda$ ciência pós moderna procura reabilitar o senso comum por reconhecer nesta forma de conhecimento algumas virtualidades para enriquecer a nossa 
relação com o mundo. É certo que o conhecimento do senso comum tende a ser um conhecimento mistificado e mistificador mas, apesar disso e apesar de ser conservador, tem uma dimensão utópica e libertadora que pode ser ampliada através do diálogo com o conhecimento científico. Essa dimensāo aflora em algumas das características do conhecimento do senso comum.

O senso comum faz coincidir causa e intençāo; subjaz-lhe uma visão do mundo assente na acçāo e no princípio da criatividade e da responsabilidade individuais. O senso comum é prático e pragmático; reproduz-se colado às trajectórias e às experiências de vida de um dado grupo social e nessa correspondência se afirma fiável e securizante. $O$ senso comum é transparente e evidente; desconfia da opacidade dos objectivos tecnológicos e do esoterismo do conhecimento em nome do princípio da igualdade do acesso ao discurso, à competência cognitiva e à competência linguística. O senso comum é superficial porque desdentha das estruturas que estāo para além da consciência, mas, por isso mesmo, é exímio em captar a profundidade horizontal das relações conscientes entre pessoas e entre pessoas e coisas. O senso comum é indisciplinar e imetódico; não resulta de uma prática especificamente orientada para o produzir; reproduz-se espontaneamente no suceder quotidiano da vida. O senso comum aceita o que existe tal como existe; privilegia a aç̧ão que não produza rupturas significativas no real. Por último, o senso comum é retórico e metafórico; não ensina, persuade.

À luz do que ficou dito atrás sobre o paradigma emergente, estas características do senso comum têm uma virtude antecipatória. Deixado a si mesmo, o senso comum é conservador e pode legitimar prepotências, mas interpenetrado pelo conhecimento científico pode estar na origem de uma nova racio- 
nalidade. Uma racionalidade feita de racionalidades. Para que esta configuração de conhecimentos ocorra é necessário inverter a ruptura epistemológica. Na ciência moderna a ruptura epistemológica simboliza o salto qualitativo do conhecimento do senso comum para o conhe cimento científico; na ciência pósmoderna o salto mais importante é o que é dado do conhecimento científico para o conhecimento do senso comum. $\mathrm{O}$ conhecimento científico pós-moderno só se realiza enquanto tal na medida em que se converte em senso comum. Só assim será uma ciência clara que cumpre a sentença de Wittgenstein, "tudo o que se deixa dizer deixa-se dizer claramente» (61). Só assim será uma ciência transparente que faz justiça ao desejo de Nietzsche ao dizer que «todo o comércio entre os homens visa que cada um possa ler na alma do outro, e a língua comum é a expressão sonora dessa alma comum» (62).

A ciência pós-moderna, ao sensocomunizar-se, nāo despreza o conhecimento que produz tecnologia, mas entende que, tal como o conhecimento se deve traduzir em auto-conhecimento, o desenvolvimento tecnológico deve traduzir-se em sabedoria de vida. É esta que assinala os marcos da prudência à nossa aventura científica. A prudência é a insegurança assumida e controlada. Tal como Descartes, no limiar da ciência moderna, exerceu a dúvida em vez de a sofrer, nós, no limiar da ciência pós-moderna, devemos exercer a insegurança em vez de a sofrer.

Na fase de transiçāo e de revoluçāo científica, esta insegurança resulta ainda do facto de a nossa reflexão epistemológica ser muito mais avançäda e sofisticada que a nossa prática cien-

(61) L. Wittgenstein, Tractatus Logico-Philosophicus. Frankfurt, Suhrkamp, 1973, 4.116.

(62) Nietzsche, «Rhetorique et Langage", Poctiqu», 5(191), p. 139. 
tífica. Nenhum de nós pode neste momento visualizar projectos concretos de investigaçāo que correspondam inteiramente ao paradigma emergente que aqui delineei. E isso é assim precisamente por estarmos numa fase de transição. Duvidamos suficientemente do passado para imaginarmos of futuro, mas vivemos demasiadamente o presente para podermos realizar nele ofuturo. Estamos divididos, fragmentados. Sabemo-nos a caminho mas não exactamente onde estamos na jornada. A condição epistemológica da ciência repercute-se na condição existencial dos cientistas. Afinal, se todo o conhecimento é auto-conhecimento, também todo o desconhecimento é auto-desconhecimento. 


\section{ÍNDICE}

O paradigma dominante

A crise do paradigma dominante

O paradigma emergente

1. Todo o conhecimento cientifico-natural é científico-social.

2. Todo o conhecimento é local e total.

3. Todo o conhecimento é auto-conhecimento.

4. Todo o conhecimento científico visa constituir-se em senso comum 